\title{
Causes for hospitalization of elderly individuals due to primary care sensitive conditions and its associated contextual factors
}

\author{
Angela Maria de Medeiros Soares ${ }^{1}$ \\ Tamires Carneiro de Oliveira Mendes ${ }^{2}$ \\ (iD) Kenio Costa Lima3 \\ Márcio Moreira de Menezes ${ }^{4}$
}

\begin{abstract}
1. Doutora em saúde coletiva pelo programa de pós-graduação em saúde coletiva da Universidade Federal do Rio Grande do Norte (PPGSCol-UFRN) do departamento de odontologia, professora substituta do departamento de Saúde Coletiva da UFRN, Natal, RN, Brasil. 2. Doutora em saúde coletiva pelo programa de pós-graduação em saúde coletiva da Universidade Federal do Rio Grande do Norte (PPGSCol-UFRN) do departamento de odontologia, Natal, RN, Brasil.

3. Pós-doutor pela Agência de Saúde Pública de Barcelona, professor associado IV da Universidade Federal do Rio Grande do Norte (UFRN) e do programa de pós-graduação em saúde coletiva da UFRN (PPGSCol) do departamento de odontologia, Natal, RN, Brasil .
\end{abstract} 4. Médico Clínico-Geral pela Universidade Potiguar. Médico da Estratégia de Saúde da Família da Unidade Básica de Saúde de Cajazeiras-RN, Brasil.

\section{SUMMARY}

OBJECTIVE: The objective of this study was to analyze the hospitalizations of the elderly for conditions sensitive to primary care (ICSAP) and associated contextual factors, referring to elderly people aged 60 and over, living in municipalities in the Northeast region.

METHODS: Characterized as being an ecological study using data from the Hospital Information System (SIH) and the Basic Attention Information System (SIAB) referring to elderly people aged 60 and over.

RESULTS: The total hospitalization rate was 527,524, with the highest number due to heart failure, followed by cerebrovascular diseases, and infectious gastroenteritis. Analyzing the ICSAP rates with the contextual factors, all were significant. Regarding the coverage of basic care, a similarity occurred between them, and for the rate of the number of consultations among the elderly, despite the greater number of these in the municipalities with higher hospitalization rates, there was no significant difference between them.

CONCLUSION: We conclude that the contextual factors interfere in the conditions of this hospitalization, necessitating, besides the improvement of primary care, an improvement in the living conditions of the elderly population.

KEYWORDS: Aged. Hospitalization. Epidemiologic factors.

\section{INTRODUCTION}

The increase in the elderly population worldwide is currently the subject of many discussions. In Brasil, this has also become relevant, since the country is going through an intense process of population aging.

This process brings many changes - psychological, physical, and emotional -, which increases the need for 
attention to the health of elderly individuals, mainly due to the increase in the number of chronic-degenerative diseases. In this context, the health system needs to adapt to this inversion of the population pyramid, including changes in primary care, which is characterized by being the first line of patient treatment. This type of care is paramount in the process of health promotion, prevention of injuries, hospitalizations, and early deaths. Effective primary care is associated with a reduction of costs, user satisfaction, and improved health indicators. ${ }^{1-4}$

To evaluate and monitor the effectiveness of primary care, a list of Hospitalizations due to Primary Care Sensitive Conditions (PCSC), published in Decree No 221 of the Ministry of Health (MS), on 17 April 2008, was drawn up and validated in Brasil. ${ }^{2}$ It comprises a number of diseases and injuries that can be prevented with timely and effective outpatient care, control of acute episodes, or management of chronic conditions and diseases. It lists a set of events that would hardly evolve to the point of requiring hospitalization if approached appropriately in outpatient care promotion, prevention, early treatment, and follow-up. ${ }^{5.6}$ By studying ICSAP, it is possible to analyze the impact of primary care based on hospitalizations database records. ${ }^{7}$

Along with these factors, it is important to evaluate the social factors that affect the population health, since studies ${ }^{5.7}$ have reported that, in addition to the improvement of basic care, it is necessary to assess the socio-economic conditions of the population so that along with the improved access to health there is also improved quality of life as a whole.

Thus, this study aims to study the degree of hospitalizations of elderly individuals in the Northeast region of Brasil, in the period from 2010 to 2015, evaluating the frequency of Hospitalizations due to Primary Care Sensitive Conditions (PCSC) and its possible relationships with contextual factors.

\section{METHODS}

This is a descriptive ecological study that included elderly individuals aged 60 years or older, residing in the northeast region of Brasil, in the years 2010 to 2015. The sample units are composed of municipalities in the region, which includes nine states and 1,794 municipalities.

We selected data of Hospitalizations due to Primary Care Sensitive Conditions (PCSC) in the municipalities, per location of residence, obtained from the
Hospital Information System (SIH), which is based on Hospital Admission Authorizations (HAA type 1).

As a dependent variable, we evaluated the rate of ICSAP in the elderly. This was calculated by the ratio between the number of ICSAP in elderly individuals residents of the municipalities of the Northeast Region and the entire elderly population in these places in the year 2010, multiplied by 6 , because it represents the period analyzed (2010-2015), for a cluster of 10 thousand inhabitants. ${ }^{7}$

In relation to the independent variables, the contextual socioeconomic variables, regarding the last census (2010), were collected from secondary sources: The Institute for Applied Economic Research (IPEA, 2015) and the Brasilian Institute of Geography and Statistics (IBGE, 2015), both in its raw form, as well as transformed into indicators by the United Nations Development Programme (UNDP, 2015). In addition to these variables, we collected data regarding the coverage of basic care in the municipalities and the number of consultations of elderly patients in primary care from the Siab, which used the rate of the number of consultations, consisting of the ratio between the total number of consultations in the years 2010-2015 and the total number of elderly people in the year 2010, multiplied by 6 , for a conglomerate of 10,000.

Based on a theoretical and statistical analysis, we selected 11 contextual variables: mean per capita income (income); illiteracy rate in the population aged 18 years old or older (illit.); percentage of the population aged 6 to 14 years old in primary education with no delay (primary-e); degree of formalization of employment (form); rate of activity of individuals aged 25 to 29 years old (actv25-29); unemployment rate of the population 18 years old or older (unemp); percentage of people employed in the agricultural sector (agro); appropriate households (house); dependency ratio (dep_ratio); urbanization rate (urb_rate), and social welfare programs (soc-well).

Since this study is based on official secondary data in public domain, there was no need for approval by the Research Ethics Committee, which followed the guidelines of the Resolution of the National Health Council (CNS) No. 466, December 12, 2012.

\section{Statistical analysis}

Of the 1,794 municipalities in the Northeast, we carried out a K-means non-hierarchical clustering analysis, which produced clusters of the northeastern 
municipalities, based on the chapters of the causes for Hospitalizations due to Primary Care Sensitive Conditions. As a result, three clusters were formed: 1,2 , and 3 , with intermediate, low, and high rates of ICSAP, consecutively.

In relation to more than 800 contextual socioeconomic variables, the selection for the multivariate analysis was based on a theoretical analysis of the dimensions of the models of Social Determinants of Health, followed by descriptive analysis, in order to identify those that best differentiate the municipalities and with a distribution closer to normality. Then, we calculated the Spearman's correlation coefficient between all the variables to select those with the greatest potential to represent the others.

We chose to summarize the set of variables selected by R-type factorial analysis, in which these variables are grouped according to the latent dimensions in its group and interpreted based on what they represent collectively. We used a correlation matrix, the measurement of the adequacy of the sample, the Bartlett test, and anti-image matrix to evaluate the correlation between the variables and the applicability of the factor analysis. The extraction of the factors was done using Principal Component Analysis (PCA), whose number of components extracted was determined by the Kaiser criterion. To facilitate the interpretation of factors, the Varimax rotation method was used.

For the PCA, we included the contextual variables that, from their correlations, were reduced to three components representing the different dimensions related to the contextual level of the Social Determinants of Health. Once we confirmed the applicability of the factor analysis by observing the correlations matrix, with the determinant different from zero (0.006), the anti-image matrix, the Bartlett test $(\mathrm{p}<0.001)$ and the Kaiser-Meyer-Olkin index $(\mathrm{KMO}=0.86)$, we proceeded to the extraction of components using the 11 variables adequate to it. Based on the Kaiser criterion, we selected three factors that, together, explained $65.3 \%$ of the total variance of the variables included in the model.

Therefore, the contextual variables were reduced to three components of the different contextual dimensions of the Social Determinants of Health, component 1, called "Urbanization and Its Reflexes"; component 2, "Favorable Socioeconomic Context"; and 3, "Low Formal Education and Dependence on the State".

In addition to these contextual variables, we also analyzed the Social Vulnerability Index (SVI), the Human Development Index (HDI) and the Firjan Index of Municipal Development (IFDM) as a way to complement the analysis with the latent variables produced by the factors.

In the analysis of the hospitalization rate of the clusters, along with the contextual variables, we used the analysis of variance with the Bonferroni test for a significance level of $5 \%$.

\section{RESULTS}

Evaluating the hospitalization of the elderly individuals due to ICSAP in the given period, the total number of ICSAP in the Northeast region was 1,727,043, with a higher number of cases due to cardiac insufficiency, followed by cerebrovascular diseases and, in third place, infectious gastroenteritis. In the analysis of ICSAP rates using a population of $32,455,176$ elderly individuals in a period of six years, we found a total rate of 527,524 hospitalizations for every 10,000 elderly inhabitants - Table 1.

After forming the clusters, according to Figure 1, we observed that in the cluster with the lowest and highest rates of hospitalization, hospitalizations due to heart failure were the most frequent, followed by gastrointestinal diseases and, in third place, by cerebrovascular diseases, which differs from the cluster with intermediate rates, in which infectious gastroenteritis were more frequent, followed by hypertension and, in third place, diabetes mellitus.

After testing the difference between the rates per ICSAP group in elderly patients with the contextual factors, according to Table 2, a significant difference was found in both clusters and the contextual variables. Cluster 3, which has the highest rates of hospitalization, was the one with the best values for the Favorable Socioeconomic Context and higher values for Low Formal Education and Dependence on the State. Cluster 2, which has lower rates of hospitalization, had the best means for the "Urbanization and Its Reflexes". In relation to the coverage of basic care, there was a similarity between the clusters, and regarding the rate of the number of consultations of elderly individuals, we found that, despite the greater number of consultations in clusters with higher rates of hospital admission, there was no significant difference between them. The VSI was higher for the clusters with intermediate rates. Whereas the IFDM was greater in the clusters with lower rates of 
TABLE 1. CAUSES OF HOSPITALIZATION OF ELDERLY INDIVIDUALS DUE TO PRIMARY CARE SENSITIVE CONDITIONS AND ITS RATES IN THE NORTHEAST REGION, 2010-2015.

\begin{tabular}{l|l|l} 
CID-10 & $\begin{array}{l}\text { Total number of ICSAP } \\
(2010-2015)\end{array}$ & $\begin{array}{l}\text { ICSAP rate } \\
(2010-2015)\end{array}$ \\
\hline 1 - Diseases preventable by immunization and sensitive conditions & 10,680 & 3.26 \\
\hline 2 - Infectious gastroenteritis and complications & 241,289 & 73.705 \\
\hline 3- Anemia & 12,189 & 3.723 \\
\hline $4-$ Nutritional deficiencies & 55,872 & 17.067 \\
\hline $5-$ Infections of the ear, nose and throat & 5,525 & 1.688 \\
\hline $6-$ Bacterial pneumonia & 69,199 & 21.138 \\
\hline $7-$ Asthma & 67,589 & 20.646 \\
\hline $8-$ Pulmonary diseases & 105,072 & 32.096 \\
\hline 9 - Hypertension & 143,963 & 43.976 \\
\hline $10-$ Angina & 71,618 & 21.877 \\
\hline $11-$ Heart failure & 291,675 & 89.096 \\
\hline $12-$ Cerebrovascular diseases & 245,564 & 75.011 \\
\hline $13-$ Diabetes mellitus & 193,189 & 59.012 \\
\hline $14-$ Epilepsy & 9,585 & 2.928 \\
\hline $15-$ Kidney and urinary tract infections & 106,097 & 32.409 \\
\hline $16-$ Infection of the skin and subcutaneous tissue & 65,521 & 20.014 \\
\hline 17 - Inflammatory disease of female pelvic organs & 1,895 & 0.579 \\
\hline $18-$ Gastrointestinal ulcers & 30,435 & 9.297 \\
\hline
\end{tabular}

Source: Ministry of Health - Hospital Information System of SUS (SIH/SUS)/Datasus/MS.

TABLE 2. DIFFERENCE IN THE RATES OF HOSPITALIZATION OF ELDERLY INDIVIDUALS DUE TO PRIMARY CARE SENSITIVE CONDITIONS IN RELATION TO CONTEXTUAL VARIABLES, 2010-2015.

\begin{tabular}{|c|c|c|c|c|}
\hline \multirow[b]{2}{*}{ Variables } & \multicolumn{3}{|c|}{ Groups per rates of causes of hospitalization of elderly individuals } & \multirow[b]{2}{*}{$\mathrm{p}$} \\
\hline & $\begin{array}{l}\text { Intermediate rates of } \\
\text { ICSAP (Cluster } 1 \text { ) } \\
\text { Mean (standard } \\
\text { deviation) }\end{array}$ & $\begin{array}{l}\text { Lower rates of ICSAP } \\
\text { (Cluster } 2 \text { ) } \\
\text { Mean (standard } \\
\text { deviation) }\end{array}$ & $\begin{array}{l}\text { Higher rates of ICSAP } \\
\text { (Cluster } 3 \text { ) } \\
\text { Mean (standard } \\
\text { deviation) }\end{array}$ & \\
\hline Urbanization and Its Reflexes & $-022(0.77) a$ & $0.06(1.05) b$ & $-0.04(0.90) a b$ & $<0.001$ \\
\hline Favorable Socioeconomic Context & $0.05(0.95) a$ & $0.00(1.00) b$ & $0.32(0.90) c$ & $<0.001$ \\
\hline $\begin{array}{l}\text { Low Formal Education and Depen- } \\
\text { dence on the State }\end{array}$ & $0.05(0.88) a$ & $-0.04(1.00) a$ & $0.29(1.09) b$ & $<0.001$ \\
\hline Social Vulnerability Index (SVI) & $0.49(0.10) a$ & $0.46(0.04) b c$ & $0.45(0.04) a \mathrm{c}$ & $<0.001$ \\
\hline Human Development Index (HDI) & $0.58(0.03) a$ & $0.59(0.10) b$ & $0.52(0.11) a b$ & 0.009 \\
\hline $\begin{array}{l}\text { Firjan Municipal Human Develop- } \\
\text { ment Index (IFDM) }\end{array}$ & $0.47(0.10) a$ & $0.52(13.1) b$ & $0.46(13.1) a$ & $<0.001$ \\
\hline BC Coverage & $93.9(10.5)$ a & $91.6(13.1) b$ & $91.2(13.1) b \mathrm{c}$ & 0.012 \\
\hline Rate of elderly consultations BC & $25850.0(98704.3)$ & 28629.8(66962.5) & $31504.7(146739.0)$ & 0.774 \\
\hline
\end{tabular}

*Different letters demonstrate the existence of significant differences between the clusters for a confidence level of $95 \%$.

hospitalization, as was the HDI, but the means were not as significantly different for these indexes.

\section{DISCUSSION}

The results obtained showed that the rate of ICSAP was 527.524 per 10 thousand inhabitants, and the three main causes of ICSAP were congestive heart failure, cerebrovascular diseases, and infectious gastroenteritis. These causes together, considered sensitive to primary care, demonstrate that good attention at this level of care could prevent such events, and these findings may represent a warning to the services of primary health care, so they can identify flaws in the care system of the entire Northeast Region.

On this same premise, studies have reported that the rates of hospitalization due to PCSC serve as indicators that are being increasingly used in the assessment of this type of care, showing that primary care 
services of better quality are associated with lower rates of hospitalization due to CSAP. ${ }^{8.9}$

The two greatest causes of ICSAP identified in this study corroborate other studies found in the literature and performed in Brasil; however, they evaluate not only the population of elderly individuals but also the population in general. In the evaluation of age groups over 60 years old, illnesses related to the circulatory system are among the main causes of ICSAP. ${ }^{1-4,9-13}$

The highest rate of hospitalization due to heart failure in the elderly population is confirmed by data published in Brasil, in which this represents the second most frequent cause of hospitalization due to CSAP. ${ }^{1.2}$ Among the risk factors for heart failure are hypertension, smoking, obesity, sedentary lifestyle, and family history, factors that can be addressed in basic care through health promotion and disease prevention.

Regarding infectious gastroenteritis, the third greatest cause of hospital admissions, they are related to social factors, such as living conditions and adequate sanitation. Studies have reported that these are more often related to the children population, with diseases linked to public health problems in Brasil, with a strong social and economic impact. ${ }^{10,12,13}$

The clusters with the lowest rates of hospitalization were also those who had the highest mean for the "Urbanization and Its Reflexes" factor, followed by the cluster with the highest rates of hospitalization. In connection with the data found, findings have reported that the process of urbanization and the consequent demographic transition contribute to an increase in chronic non-communicable diseases,${ }^{14}$ because this process generates industrial development, unhealthy life habits, and environmental pollution, factors that contribute to a greater increase of $\mathrm{CNCD},{ }^{10}$ which explains the greater number of diseases caused by heart failure in the clusters mentioned.

Favorable Socioeconomic Context was also predominant in the cluster with the highest rates of hospitalization. This larger number may be related to greater use of hospital services by elderly individuals, which is related to the higher number of cases of chronic diseases in this stage of life, often with greater intensity and severity, which increases the number of hospitalizations, regardless of social class. In addition, elderly individuals with favorable socioeconomic context also use hospital services often. ${ }^{14}$

The Low Formal Education and Dependence on the State factor also had the highest mean in clusters with higher rates of hospital admission. This finding is related to the precariousness of services in primary care, since this factor includes people with greater dependence of state health services, and these higher rates may reflect a deficit in primary care, which would entail a greater number of hospitalizations, assuming CSAP was not solved in basic care. In addition, the population with this profile has, consequently, greater exposure to risk factors such as tobacco use, poor diet, among other risk factors related to chronic diseases. ${ }^{10.12}$

A study carried out in the districts of the municipality of Goiânia also had similar findings, districts that had better socioeconomic contexts had higher rates of hospitalization. The study concluded that this result was motivated by a lack of access to primary health care. ${ }^{12}$

When analyzing the number of consultations of elderly individuals in primary care, there was no significant difference. The factor does not portray the effectiveness of basic care and its relationship with a greater or lower frequency of ICSAPS in the clusters. It is also important that, in addition to evaluating the primary care, we evaluate the other networks of health services, because their appropriate structuring can provide improvements in the health care of elderly individuals, reducing hospitalizations due to CSAP.

Another study related to the creation of the Family Health Strategy (ESF) with the ICSAP. The results showed no correlation between its expansion and the decrease of ICSAP. Although the population coverage by the FHS has increased in all regional health services of the cities studied, this did not happen evenly. ${ }^{15}$ Studies with 1,622 Brasilian municipalities have also identified a negative correlation between FHS coverage and ICSAP. ${ }^{16}$

It is stressed that the implementation of the FHS has expanded the coverage of basic care and contributed to the organization of a care model that used the health of the family as a first-line health service. However, this was likely not accompanied by a corresponding improvement in the level of organization and practices of these services, which did not reach the expected levels of effectiveness, and did not follow the improvement in the quality of life of the elderly population, since we observed significant differences between contextual factors and the number of ICSAP in the municipalities.

This is also due to the lack of efforts to improve the integrality of care by many health professionals, 
since this principle takes into account not only the disease but the individual as a whole, including the social determinants of health. A study carried out in Porto Alegre ${ }^{17}$ reported that, when assessing the effectiveness of the integrality of care, significant problems were found. Some explanations were related; evidence shows that the basic health units still operate under the biomedical logic that focuses on the diseases, and not on the individual, and have lower scores of integrality when compared to the ESFs and to the educational units who have a Multiprofessional Residency. This finding is possibly related to the challenge of breaking away from the traditional care model of such establishments. ${ }^{18.19}$

The shift towards integrality requires a rupture from the biomedical model through policies of family health prioritization, changes in the building of human resources, and the logic of care that disregards the use of protocols and evidence in the APS care. In addition, the Family Health Strategy also has limitations that may hinder the process for integral care, such as the precarization of work contracts and the absence of Family Health Support Centers. ${ }^{17-19}$

Authors have reported that, when assessing the primary care coverage or the number of consultations, it is necessary to check beyond the quality of primary care that it can reflect since there are other factors associated with the results, such as the adequacy of the professionals, mainly the permanence of physicians; the association to social, economic, political, and environmental determinants; and other aspects of the structural dimension. ${ }^{10.16}$

The findings of the present study reflect the importance of studying the ICSAP in elderly individuals and monitoring social determinants of health, which will reflect on further assistance to the activity of health promotion among elderly individuals and, consequently, will reduce diseases related to the CSAP and improve the quality of life.

Regarding the limitations of the present study, it is worth noting that this paper is limited to initial hospitalizations, in which there may be diagnostic errors at the time of admission, which could mask some of the causes. However, it should be emphasized that this study corroborates several others in the literature, which confirms the most common findings.

\section{CONCLUSION}

We found a predominance of diseases due to heart failure in Hospitalizations due to Primary Care Sensitive Conditions and that contextual factors interfere in the conditions of admission. This makes us conclude that, besides the improvement of primary care, it is necessary to improve the living conditions of the elderly population, because this has great potential for reducing injuries and complications caused by chronic diseases in this population. Therefore, it is essential that public policies work in interventions that ensure care for chronic diseases and strengthen the promotion of healthy aging.

\section{Author Contributions}

A. M. M. Soares was responsible for a good part of the writing of this document and data collection; T. C. O. Mendes performed the statistical analyses; M. M. Menezes contributed in data collection and in writing the article; K. C. Lima advised the entire study.

\section{RESUMO}

OBJETIVO: Objetivou-se realizar uma análise das internações dos idosos por condições sensíveis à atenção primária (ICSAP) e fatores contextuais associados em idosos com 60 anos ou mais, residentes em municípios da Região Nordeste.

MÉTODOs: Caracterizou-se por ser um estudo ecológico utilizando dados do Sistema de Informação Hospitalar (SIH) e do Sistema de Informação da Atenção Básica (Siab) referentes a idosos com 60 anos ou mais.

RESULTADOS: A taxa total de internação foi de 527,524, sendo em maior quantidade aquelas por insuficiência cardíaca, seguidas das doenças cerebrovasculares e, em terceiro, as gastroenterites infecciosas. Analisando as taxas de ICSAP com os fatores contextuais, todas foram significativas. Em relação à cobertura da atenção básica, ocorreu uma similaridade entre eles, e para a taxa do número de consultas entre idosos, apesar do maior número destas nos municípios com maiores taxas de internação, não existiu diferença significativa entre eles.

CONCLUSÃo: Concluímos que os fatores contextuais interferem nas condições dessa internação, necessitando, além da melhoria da atenção primária, uma melhoria nas condições de vida da população idosa.

PALAVRAS-CHAVE: Idoso. Hospitalização. Fatores epidemiológicos. 


\section{REFERENCES}

1. Junqueira RMP, Duarte EC. Internações hospitalares por causas sensíveis à atenção primária no Distrito Federal, 2008. Rev Saúde Pública. 2012;46(5):761-8.

2. Alfradique ME, Bonolo PF, Dourado I, Lima-Costa MF, Macinko |, Claunara Schilling Mendonça CS, et al. Internações por condições sensíveis à atenção primária: a construção da lista brasileira como ferramenta para medir o desempenho do sistema de saúde (Projeto ICSAP - Brasil). Cad Saúde Pública. 2009;25(6):1337-49.

3. Marques AP, Montilla DER, Almeida WS, Andrade CLT. Internação de idosos por condições sensíveis à atenção primária à saúde. Rev Saúde Pública. 2014;48(5):817-26.

4. Marques AP. Análise das causas de internação de idosos segundo a classificação de Condições Sensíveis à Atenção Primária: estudo da evolução temporal no Estado do Rio de Janeiro. [Dissertação de Mestrado]. Rio de Janeiro: Escola Nacional de Saúde Pública Sergio Arouca; 2012. $71 f$.

5. Giovanella L, Mendonça M. Atenção primária à saúde. Políticas e Sistemas de Saúde no Brasil. Rio de Janeiro: Fiocruz; 2008. p.575-625.

6. Gill TM, Allore HG, Holford TR, Guo Z. Hospitalization, restricted activity, and the development of disability among older persons. JAMA. 2004;292(17):2115-24.

7. Oliveira MLC, Amancio TG. Situações de saúde, vida e morte da população idosa residente no Distrito Federal. Curitiba: CRV; 2016.

8. Starfield B. Atenção primária: equilíbrio entre necessidades de saúde, serviços e tecnologia. Brasília: Unesco; Ministério da Saúde; 2002.

9. Muraro CF, Gigante LP, Nedel FB, Carvalho TGML, Domenech SC, Gevaerd MS. Estratégia saúde da família e as internações por condições sensíveis a atenção primária nos idosos. Rev Baiana Saúde Pública. 2013;37(1):20-33.

10. Melo MD, Egry EY. Determinantes sociais das internações por condições sensíveis à atenção primária em Guarulhos, São Paulo. Rev Esc Enferm USP. 2014;48(n.esp):133-40.
11. Pazó RG, Frauches DO, Galvêas DP, Stefenoni AV, Cavalcante ELB, Pereira-Silva FH. Internações por condições sensíveis à atenção primária no Espírito Santo: estudo ecológico descritivo no período 2005-2009. Epidemiol Serv Saúde. 2012;21(2):275-82.

12. Magalhães ALA, Morais Neto OL. Desigualdades intraurbanas de taxas de internações por condições sensíveis à atenção primária na região central do Brasil. Ciência \& Saúde Coletiva. 2017;22(6):2049-62.

13. Cavalcante DM, Oliveira MRF, Rehem TCMSB. Estudo de validação do SIH/SUS em Hospital do Distrito Federal. Cad Saúde Pública. 2016;32(3):e00169914.

14. Loyola Filho Al, Matos DL, Giatti L, Afradique ME, Peixoto SV, Lima-Costa MF. Causas de internações hospitalares entre idosos brasileiros no âmbito do Sistema Único de Saúde. Epidemiol Serv Saúde. 2004;13(4):229-38.

15. Rodrigues-Bastos RM, Campos EMS, Ribeiro LC, Bastos Filho MG, Bustamante-Teixeira MT. Internações na avaliação da atenção primária. Rev Saúde Pública. 2014;48(6):958-67.

16. Macinko J, Dourado I, Aquino R, Bonolo PF, Lima-Costa MF, Medina MG, et al. Major expansion of primary care in Brazil linked to decline in unnecessary hospitalization. Health Aff (Millwood). 2010;29(12):2149-60.

17. Castro RCL, Knauth DR, Harzheim E, Hauser L, Duncan BB. Avaliação da qualidade da atenção primária pelos profissionais de saúde: comparação entre diferentes tipos de serviços. Cad Saude Publica. 2012;28(9):1772-84.

18. Brasil. Ministério da Saúde. Secretaria de Atenção à Saúde. Departamento de Atenção Básica. Diretrizes do NASF: Núcleo de Apoio a Saúde da Família. Brasília: Ministério da Saúde; 2010.

19. Martins $A B$, D'Avila $O P$, Hilgert |B, Hugo FN. Atenção primária a saúde voltada as necessidades dos idosos: da teoria à prática. Ciênc Saúde Coletiva. 2014;19(8):3403-16 